\title{
Identification of the Therapeutic Effects of Gamma-irradiated Chamomile Aqueous Extract Against Alcohol Induced Hepato- nephrotoxicity in Rats
}

\author{
M.H.M. Abd El-Megid*, A. M. Abdul Azeem**, A.N. El-Shahat**and H. M. S. \\ Mekawey** \\ *Natural ProductsDepartment, **Food Irradiation Research Department, National \\ Centre for Radiation Research and Technology (NCRRT), Atomic Energy Authority, \\ P.O. Box: 29 Nasr City, Cairo, Egypt.
}

\begin{abstract}
LCOHOL consumption represents the third largest risk factor for disease burden in most 1 countries of the world and can damage several organs and systems in the body such as liver and kidney. Medicinal herb plants may act as an effective remedy for the enormous health burden posed by alcohol consumption. The aim of this study is to investigate the therapeutic effects of an aqueous extract of gamma-irradiated chamomile (GCE) (10 kGy) on alcoholinduced hepato-nephrotoxicity in rats. In this study, results of rats that received alcohol alone (1 $\mathrm{ml}$ of $70 \%$ ethanol daily for 56 days) showed hepato-nephrotoxicity as indicated by significant increases in the activity of hepatic enzyme markers. These changes include:increased levels of serum creatinine, urea and uric acid with significant decreased levels of total protein, albumin and globulin. Ethanol administration also resulted in elevation inmalondialdehyde (MDA) concentration and the activity of xanthine oxidase (XO) andalcohol dehydrogenase (ADH) with reduction inglutathione level (GSH) and the activities ofaldehyde dehydrogenase (ALDH) ,xanthine dehydrogenase (XDH), superoxide dismutase (SOD) and catalase (CAT) in both liver and kidney tissues compared to control rats. Post-treatment of ethanol-administered rats with aqueous gamma-irradiated chamomile extract significantly ameliorates the deleterious effects of ethanol on all biochemical parameters and enhances the hepato-renal antioxidant status and improved alterations in hepatic alcohol metabolizing enzymes. It could be concluded that gamma-irradiated chamomile can be suggested to providea distinct treatment against ethanol induced organ damage.
\end{abstract}

Keywards : Chamomile, Alcohol, Hepatotoxicity, Nephrotoxicity, Gamma-irradiation.

\section{Introduction}

Worldwide, acute or chronic alcohol beverages abuse induced a major health problem and can result into several metabolic disorders in hepatic and extra-hepatic diseases (Oyenihi et al., 2016). Over production of free radicals and cellular damage resulting from excessive alcohol consumption increases the formation of oxidative stress biomarkers such as malondialdehyde (MDA), diminished antioxidant enzyme activities and decreases the glutathione level (Oyenihi et al., 2016). Due to its water and fat soluble properties, ethanol has the ability to permeate all tissues and affect almost all organs of the body,such as liver and kidney (Mani et al., 2016). The toxicity of alcohol is associated with its metabolism through alcohol dehydrogenase (ADH) which converts ethanol to the toxic acetaldehyde which is finally oxidized to acetate through aldehyde dehydrogenase (ALDH). Acetaldehyde is a toxic by-product metabolite of ethanol that leads to liver damage (Purohit et al., 2003). Acute alcohol intoxication or chronic alcoholism leads to renal damage. Protein deficiency and enzyme activity impairment with a decreased concentration of serum albumin and alteration in enzyme activities have also been associated with alcoholic liver disease (ALD) (Ozaras et al., 2003).

The development and identification of an effective renal and heapto protective agent will be a useful tool for the treatment against alcohol toxicity. The detoxification of free radicals and 
antioxidant properties of medicinal plants may be related to its natural polyphenolic compounds (Mannaa et al., 2015). Chamomile (Matricaria recutita $\mathrm{L}$.) is one of the most ancient herbal medicine plant belonging to Compositae family and most popularly consumed beverages worldwide (Jabri et al., 2016). Chamomile contains a large number of therapeutically interesting active and potential sources of antioxidant compounds due to flavones, falvenols, isoflavones, flavonoids, anthocyanin, cumarin, tannic acid, and isocatechins (Al-Refai et al., 2014). These pharmacological compounds of chamomile have the ability to scavenge free radicals and/or inhibit lipid peroxidation (Sebai et al., 2014). Moreover, chamomile exhibits many beneficial health effects such as antiinflammatory, anti-oxidant properties, neuroprotective, anti-allergic, anti-bacterial properties and anti-cancer activities (Jabri et al., 2016).

Gamma radiation is the physical and nonthermal effective process and one of the latest techniques used world-wide in food preservation. Radiation processing technology improves hygiene, quality and safety and prevents the growth of microorganisms and insect damage in order to extend the shelf life of perishable food and herbal material products. (IAEA, 1992 and Farkas, 1998). It reduces the dependence on fumigants when using chemical hazardous compounds and preservatives currently used by the food and pharmaceutical industries. The chances of recontamination are also reduced, as it can be done after packaging. Meanwhile, there is a scientific concernon the effect of gamma irradiation processes on the antioxidant properties and the compounds responsible for such activity (Ghadi et al., 2015). Numerous studies on plant materials showed that the potential tool of gamma irradiation maintain / enhance antioxidant activity (Jo et al., 2003). On the other hand,other studies have shown that gamma irradiation diminished the activity of antioxidants (Ahn et al., 2005) in plant materials. Therefore, the present work aimsto assess the antioxidant activities of watery extract gamma-irradiated chamomile (GCE) against alcohol induced hepato-renal toxicity and oxidative stress in rats.

\section{Materials and Methods}

Chemicals and Reagents

The chemicals and reagents were purchased from Sigma-Aldrich (St. Louis, MO, USA).

\section{Plant Materials}

Dried chamomile (Matricaria chamomilla) flowers were purchased from local market, Cairo, Egypt.

\section{Gamma Irradiation Treatment}

Chamomile dried powder (CDP) was transferred into polyethylene bags and treated with $10 \mathrm{kGy}$ of gamma rays, using a ${ }^{60} \mathrm{Co}$ source at a dose rate of $2.50 \mathrm{kGy} / \mathrm{h}$ at the National Centre for Radiation Research and Technology (NCRRT), Egypt.

\section{Extraction of Chamomile}

The aqueous extracts of either raw (RCE) or gamma-irradiated (GCE) dried chamomile powder were prepared using (10 g) dried material in $100 \mathrm{ml}$ distilled water brought to boil for $5 \mathrm{~min}$. at $100^{\circ} \mathrm{C}$ (Kassi et al., 2004), then $0.25 \mathrm{gm} / \mathrm{Kg}$ body weight (equivalent to $2.5 \mathrm{ml}$ ) of clear solution was given orally every day throughout the duration of the experiment to chamomile treated group (Abid et al., 2012).

\section{Doses and Treatment}

Alcoholism was experimentally induced in animals by giving rats $1 \mathrm{ml}$ of $70 \%$ ethanol (Nwoye, 2013). Raw and gamma-irradiated chamomile watery extract (RCE or GCE) was adjusted to $0.25 \mathrm{gm} / \mathrm{kg}$ b. wt. (Abid et al., 2012) and were given daily to rats.

\section{Animals}

Adult male albino rats, weighing $180 \pm 20$ gm were purchased from the Animal House Colony of the Veterinary Serum and Vaccine Research Institute, Cairo, Egypt. Rats were housed under conventional laboratory conditions throughout the period of the experimentation and fed standard rat pellet diet and allowed free access to water.

\section{Experimental Design:}

The animal used were randomly divided into 4 groups, each consisted of 7 rats. All treatments were administered orally to theanimals once daily using cavage needles.

Control group: Animals treated orally with water daily for 56 days.

Ethanol treated group (EtOH. group): rats were given $1 \mathrm{ml}$ of $70 \%$ ethanol (Nwoye, 2013) 
daily for 56 days.

RCE treated group (EtOH\& RCE): rats were first given $1 \mathrm{ml}$ of $70 \%$ ethanol for the 28 days followed by daily administration of raw chamomile watery extract $(0.25 \mathrm{gm} / \mathrm{Kg} \mathrm{b}$. wt. $)$ (Abid et al., 2012) daily for another 28 days.

GCE treated group (EtOH \& GCE): rats were first given $1 \mathrm{ml}$ of $70 \%$ ethanol for the 28 days followed by daily administration of watery gammairradiated chamomile extract $(0.25 \mathrm{gm} / \mathrm{Kg} \mathrm{b}$. wt. $)$ (Abid et al., 2012) daily for another 28 days.

At the end of the experiment, animals from each group were sacrificed $24 \mathrm{~h}$ post the last dose of treatment. Blood samples were withdrawn by cardiac puncture after slight anesthesia of rats using diethyl ether and allowed to coagulate and centrifuged to get serum for biochemical analysis. Also, liver and kidney were directly removed for biochemical investigation.

\section{Biochemical Analysis}

The activity of serum aspartate transaminase (AST) and alanine transaminase (ALT) was estimated according to Reitman and Frankel (1957), serum gamma glutamyl transferase (GGT) was assessed according to Rosalki (1975) and serum alkaline phosphatase activity (ALP) was assessed according to Kind and King (1954). Serum urea was measured by enzymatic colorimetric method as described by Coulomb and Farreau (1963), serum creatinine was measured by the method of Husdan and Rapoport (1968) and serum uric acid was measured by the method of Caraway (1995). Total protein was estimated by method of Lowry et al.(1951) and serum albumin was estimated by the method of Doumas et al. (1971). Serum globulin concentration was calculated using the formula: globulins $=$ total proteins - albumin .

Liver and kidney were dissected, thoroughly washed with ice-cold $0.9 \% \mathrm{NaCl}$, weighed, minced and homogenized $(10 \% \mathrm{w} / \mathrm{v})$ using 66 $\mathrm{mmol} / \mathrm{L}$ chilled phosphate buffer $(\mathrm{pH}$ 7.0). The tissue homogenates were centrifuged at 6000 $\mathrm{rpm}$ for $15 \mathrm{~min}$. and the supernatants were used to estimate the level of malondialdehyde (MDA) (Yoshioka et al., 1979). The activity of xanthine oxidase (XO) and xanthine dehydrogenase (XDH) (Kaminski and Jewezska, 1979), glutathione content (GSH)(Gross et al., 1967) and the activity of superoxide dismutase (SOD) as (Minami and Yoshikawa, 1979) and catalase (CAT) (Aebi, 1984). Alcohol dehydrogenase (ADH) and aldehyde dehydrogenase (ALDH) were assayed in the liver homogenate by the method of Agarwal and Goedde (1990).

\section{Statistical Analysis}

Results were presented as mean \pm SE $(n=$ 7). Experimental data were analyzed using one way analysis of variance (ANOVA). Duncan's multiple range test was used to P-value determine significant differences between means. Statistical analyses were performed using computer program Statistical Packages for Social Science (SPSS, 1998). Differences between means were considered significant at $\mathrm{P}<0.05$.

\section{$\underline{\text { Results }}$}

Ethanol-injected rats showed significantly elevated activities of liver markers enzymes AST, ALT, ALP, and GGT as compared to the control, whereas on supplementation with RCE and GCE

TABLE 1. Effect of RCE and GCE treatment on the hepatic marker enzymes of ethanol-administrated rats .

\begin{tabular}{|lcccc|}
\hline \multicolumn{1}{|c}{ Parameters } & C & EtOH & EtOH \& RCE & EtOH \& GCE \\
AST $(\mathbf{U} / \mathbf{m l})$ & $33.95^{\mathrm{c}} \pm 1.83$ & $61.13^{\mathrm{a}} \pm 3.11$ & $44.62^{\mathrm{b}} \pm 1.68$ & $42.33^{\mathrm{b}} \pm 2.16$ \\
ALT $(\mathbf{U} / \mathbf{m l})$ & $25.23^{\mathrm{c}} \pm 0.78$ & $38.88^{\mathrm{a}} \pm 0.81$ & $30.15^{\mathrm{b}} \pm 0.76$ & $29.72^{\mathrm{b}} \pm 0.85$ \\
ALP(U/100ml) & $8.28^{\mathrm{c}} \pm 0.43$ & $15.81^{\mathrm{a}} \pm 0.57$ & $11.11^{\mathrm{b}} \pm 0.43$ & $10.96^{\mathrm{b}} \pm 0.74$ \\
$\boldsymbol{\gamma} \mathbf{G T}(\mathbf{U} / \mathbf{m l})$ & $4.43^{\mathrm{c}} \pm 0.39$ & $6.75^{\mathrm{a}} \pm 0.63$ & $5.42^{\mathrm{b}} \pm 0.55$ & $5.29^{\mathrm{b}} \pm 0.48$ \\
\hline
\end{tabular}

Values are expressed as means \pm S.E. $(n=7)$.

Values in the same row with different superscripts are differing significantly at $\mathrm{P}<0.05$.

to ethanol fed rats, the activities of these enzymes were significantly decreased as compared to the ethanol alone fed rats (Table 1).
Significantly reduced levels of serum total proteins, albumin, and globulin were observed in ethanol-fed rats as compared to the control rats. On supplementation with RCE and GCE, the levels 
TABLE 2. Effect of RCE and GCE treatment on levels of serum total proteins, albumin, and globulin of serum total proteins, albumin, and globulin of ethanol-administrated rats.

\begin{tabular}{|lcccc|}
\hline \multicolumn{1}{|c}{ Parameters } & C & EtOH & EtOH \& RCE & EtOH \& GCE \\
Total proteins (g/dl) & $5.97^{\mathrm{a}} \pm 0.59$ & $2.62^{\mathrm{c}} \pm 0.21$ & $4.64^{\mathrm{b}} \pm 0.41$ & $4.75^{\mathrm{b}} \pm 0.43$ \\
Albumin (g/dl) & $3.68^{\mathrm{a}} \pm 0.28$ & $1.32^{\mathrm{c}} \pm 0.10$ & $2.88^{\mathrm{b}} \pm 0.23$ & $2.96^{\mathrm{b}} \pm 0.27$ \\
Globulin (g/dl) & $2.37^{\mathrm{a}} \pm 0.21$ & $1.28^{\mathrm{c}} \pm 0.11$ & $2.02^{\mathrm{b}} \pm 0.18$ & $2.27^{\mathrm{a}} \pm 0.18$ \\
\hline
\end{tabular}

Values are expressed as means \pm S.E. $(n=7)$.

Values in the same row with different superscripts are differing significantly at $\mathrm{P}<0.05$.

of serum proteins were elevated significantly as compared to the ethanol alone administered rats (Table 2).
The serum levels of urea, uric acid, and creatinine were significantly increased in the ethanol treated rats as compared to the control.

TABLE 3. Effect of RCE and GCE treatment on the serum levels of urea, uric acid, and creatinine of ethanoladministrated rats.

\begin{tabular}{|lcccc|}
\hline \multicolumn{1}{|c}{ Parameters } & C & EtOH & EtOH \& RCE & EtOH \& GCE \\
Urea $(\mathbf{m g} / \mathbf{d l})$ & $26.27^{\mathrm{c}} \pm 0.59$ & $51.65^{\mathrm{a}} \pm 0.68$ & $32.63^{\mathrm{b}} \pm 0.51$ & $32.12^{\mathrm{b}} \pm 0.56$ \\
Uric acid(mg/dl) & $3.76^{\mathrm{c}} \pm 0.25$ & $7.88^{\mathrm{a}} \pm 0.37$ & $5.18^{\mathrm{b}} \pm 0.37$ & $4.92^{\mathrm{b}} \pm 0.35$ \\
Creatinine $(\mathbf{m g} / \mathbf{d l})$ & $0.91^{\mathrm{c}} \pm 0.07$ & $2.05^{\mathrm{a}} \pm 0.08$ & $1.33^{\mathrm{b}} \pm 0.06$ & $1.29^{\mathrm{b}} \pm 0.07$ \\
\hline
\end{tabular}

Values are expressed as means \pm S.E. $(n=7)$.

Values in the same row with different superscripts are differing significantly at $\mathrm{P}<0.05$.

Treatment of ethanol-administrated rats with either RCE or GCE showed significant decreases in the levels of serum urea, uric acid, and creatinine as compared to the ethanol alone fed rats (Table 3).
Ethanol intoxication resulted in statistically significant increases in MDA and XO and decreases in GSH level and the activity of XDH, SOD and CAT in both liver and kidney compared to control

TABLE 4. Effect of RCE and GCE treatment on the hepato-renal antioxidant status of ethanol-administrated rats.

\begin{tabular}{|c|c|c|c|c|c|}
\hline Parameters & & $\mathbf{C}$ & EtOH & EtOH \& RCE & EtOH \& GCE \\
\hline \multirow{2}{*}{$\begin{array}{l}\text { MDA } \\
\text { (n mol/g tissue) }\end{array}$} & Liver & $158.33^{\mathrm{c}} \pm 2.87$ & $247.47^{a} \pm 5.75$ & $179.25^{b} \pm 2.51$ & $173.34^{b} \pm 2.63$ \\
\hline & Kidney & $165.22^{c} \pm 3.56$ & $257.17^{\mathrm{a}} \pm 6.31$ & $182.35^{\mathrm{b}} \pm 3.11$ & $180.45^{b} \pm 3.25$ \\
\hline \multirow{2}{*}{ XO (mU/mgprotein) } & Liver & $2.23^{\mathrm{c}} \pm 0.08$ & $4.14^{\mathrm{a}} \pm 0.14$ & $2.71^{b} \pm 0.09$ & $2.66^{b} \pm 0.08$ \\
\hline & Kidney & $1.52^{\mathrm{c}} \pm 0.07$ & $2.62^{\mathrm{a}} \pm 0.08$ & $1.82^{b} \pm 0.06$ & $1.78^{\mathrm{b}} \pm 0.06$ \\
\hline \multirow{2}{*}{$\begin{array}{l}\text { XDH } \\
\text { (mU/mgprotein) }\end{array}$} & Liver & $3.27 \mathrm{a} \pm 0.08$ & $1.54 \mathrm{~d} \pm 0.07$ & $2.35^{\mathrm{c}} \pm 0.08$ & $2.85^{b} \pm 0.07$ \\
\hline & Kidney & $2.76^{\mathrm{a}} \pm 0.05$ & $1.12^{\mathrm{d}} \pm 0.07$ & $2.11^{\mathrm{c}} \pm 0.04$ & $2.40^{b} \pm 0.05$ \\
\hline \multirow{2}{*}{$\begin{array}{l}\text { GSH } \\
\text { (mg/g tissue) }\end{array}$} & Liver & $27.45^{\mathrm{a}} \pm 2.66$ & $19.58^{c} \pm 0.73$ & $24.35^{\mathrm{b}} \pm 0.29$ & $24.62^{b} \pm 0.47$ \\
\hline & Kidney & $22.63^{\mathrm{a}} \pm 1.57$ & $13.76^{\mathrm{c}} \pm 0.72$ & $18.79^{b} \pm 0.65$ & $18.83^{b} \pm 0.86$ \\
\hline \multirow{2}{*}{$\begin{array}{l}\text { SOD } \\
\text { (U/mg protein) }\end{array}$} & Liver & $47.73^{a} \pm 3.68$ & $30.14^{\mathrm{d}} \pm 2.10$ & $40.67^{\mathfrak{c}} \pm 3.15$ & $43.95^{b} \pm 3.11$ \\
\hline & Kidney & $28.44^{\mathrm{a}} \pm 1.37$ & $17.65^{\mathrm{d}} \pm 0.92$ & $22.86^{\mathrm{c}} \pm 1.11$ & $24.78^{\mathrm{b}} \pm 1.54$ \\
\hline \multirow{2}{*}{$\begin{array}{l}\text { CAT } \\
\text { (U/mg protein) }\end{array}$} & Liver & $53.02^{\mathrm{a}} \pm 1.45$ & $35.65^{\mathrm{c}} \pm 0.96$ & $46.77^{b} \pm 1.11$ & $47.22^{b} \pm 0.81$ \\
\hline & Kidney & $38.32^{\mathrm{a}} \pm 1.47$ & $19.83^{\mathrm{c}} \pm 1.22$ & $30.33^{\mathrm{b}} \pm 1.24$ & $31.41^{\mathrm{b}} \pm 1.40$ \\
\hline
\end{tabular}

Values are expressed as means \pm S.E. $(n=7)$

Values in the same row with different superscripts are differing significantly at $\mathrm{P}<0.05$.

Egypt.J.Rad. Sci. Applic. 39, No.1 (2017) 
rats. Treatment with RCE and GCE resulted in a significant improvement in these parameters in both liver and kidney tissues (Table 4).

Figure 1 shows the activities of $\mathrm{ADH}$ and
ALDH in the liver of the control and experimental rats. Ethanol-fed rats showeda significant increase in the activityof $\mathrm{ADH}$ and a significant decrease in the ALDHactivity as compared to those of the controlrats. Supplementation with either RCE

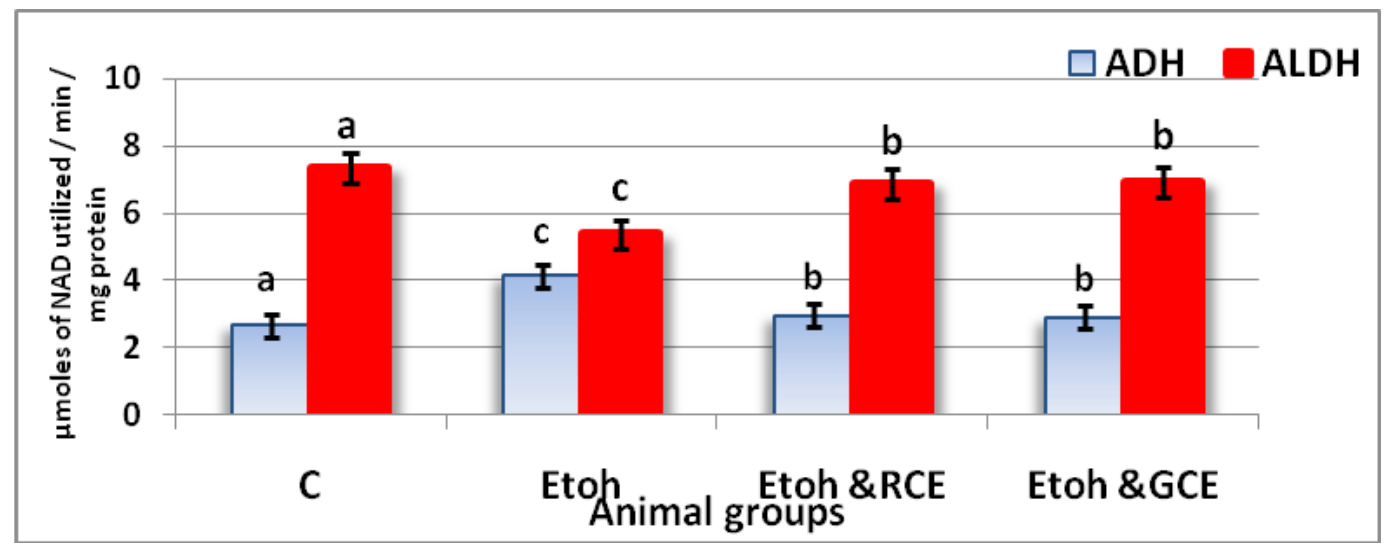

Fig. 1. Effect of RCE and GCE treatment on hepatic alcoholmetabolizing enzymes of ethanol-administrated rats. Values are expressed as means \pm S.E. $(n=7)$.

Values with different superscripts are differing significantly at $\mathrm{P}<0.05$.

or GCE toethanol-administrated rats, showed a significant decreasein $\mathrm{ADH}$ and an increase in the ALDH activities ascompared to the ethanol alone fed rats.

\section{Discussion}

The central role of the liver and kidney in drug metabolism and disposal of toxic material predisposes these organs to toxic injury. Ethanol or its metabolites can induce a sharp increase of free radicals in the human body (e.g. hepatic cells) by acting as a pro-oxidant or by reducing antioxidant levels and contributing to the progression of a variety of chronic diseases (Abou Seif, 2014). The majority of chamomile pharmacological mechanisms oractivities is related to its potential antioxidant properties which are mainly related to its ability to the scavenging activity of free radicals and/or inhibiting lipid peroxidation (Jabri et al., 2016).

As for serum enzymes related to liver function, the alcohol-administered rats exhibited a significant increase in ALT, AST, GGT and ALP activities. These results are in agreement with Padmanabhan and Jangle (2014) who illustrated that alcohol feeding induces increases in serum activities of AST, ALT, ALP, GGT and $\mathrm{LDH}$ enzymes which are markers of liver damage. Alcohol intoxication, as a result of structural changes leads to a significant increase in the cell membrane permeability to ions. This, in turn, causes leakage of ALT and AST enzymes into blood circulationas shown by abnormally high levels of serum hepatic markers (Abou Seif, 2014).

This study also revealed diminished levels of total proteins, albumin, and globulin in ethanoladministrated rats compared to control group. Ethanol prevents the synthesis of protein in the liver therefore, leads to hypo-albuminemia (Albumin deficiency. This is one of the important para clinic tests for diagnosis of chronic ALD (Das and Vasudevan, 2005). The decrease in the level of protein may be due to the necrosis of cells and result in protein synthesis problem (Singh and Singh, 2002).

In addition to the liver and the kidney functions also affected remarkably on ethanol administration as evidenced by the significant increase inrenal function marker levels such as serum urea, uric acid, and creatinine in ethanol treated rats as compared to the control. This increase is also caused mainly by the increase of acetaldehyde production which mediates tissue damage and finally leads to a decline in the glomerular filtration rate, altered kidney 
functions, and renal failure (Mani et al.,2016). Saravanan and Nalini (2007) observed that the serum urea level and creatinine were significantly increased after administering $5 \mathrm{~g} / \mathrm{kg}$ body weight/ day of ethanol for 60 days to male rats.

Regarding the hepato-renal effect of chamomile against toxic effect of ethanol in this study, the results showed that post-treatment of ethanol-administrated rats with either RCE or GCE resulted in a significant reduction in the activity of liver enzyme markers, serum levels of urea, uric acid, and creatinine. This was associated, however, with a remarkable elevation of total proteins, albumin, and globulin levels of the group of rats that received ethanol alone. These results agreed with those of Gupta and Misra (2006) who concluded that chamomile extract functions as a hepatoprotective agent cause a reduction of the elevated serum levels of ALT and AST and this activity may be due to normalization of impaired membrane function activity. Najla et al. (2012) studied the effect of hypoglycemic of chamomile leave extract and observed that the activity of AST, ALT and ALP and the values of urea, creatinine and uric acid were reduced after chamomile treatment in diabetic rats. Also, Nwoye (2013) observed that the pre-treatment or post-treatment with chamomile aqueous extract to ethanol administered rats significantly increased the serum levels of total proteins and albumin. He indicated that chamomile aqueous extract has the ability to normalizeliver function by stimulating regeneration of hepatic tissue and increase protein synthesis.

The results of this work shows that ethanolintoxication induced oxidative liver and kidney damage as demonstrated by a significant increase in MDA and $\mathrm{XO}$ and diminished in GSH level and the activity of XDH, SOD and CAT in the hepatic and renal tissues of ethanoladministrated rats compared to control group. Increased reactive oxygen species ROS, partly promoted from acetaldehyde oxidation during ethanol metabolism, which may contribute to the occurrence of oxidative stress in kidney tissues (Rodrigo et al., 1998). Abbondanza et al., (1989) reported an elevation in the XOD activity after repeated alcohol administration and an increase in the intermediate $\mathrm{XDH} / \mathrm{XOD}$ after prolonged alcohol feeding. The acute administration of alcohol significantly elevated the plasma xanthine oxidase activity in both rats and hamsters (Zima et al., 1993). An over-production of free radicals through the intervention of XOD after alcohol administration could also result from substrates different from acetaldehyde and have greater affinities for XOD (Nordmann et al., 1992). Numerous reportsstated that GSH level was decreased in kidney tissue of alcohol treated rats (Rodrigo et al., 2002 and Kode et al., 2004). The reactive oxygen intermediates generated during alcohol metabolism leads to GSH oxidation resulting in the depletion/reduction of GSH (Balasubramaniyan et al., 2003).

Moreover, the hepatic ADH activity was high and that of ALDH activity was significantly depressed in ratsfed ethanol when compared to the control rats. This suggests that damaged hepatic cells have a major capability for alcohol oxidation and considerably less ability to remove acetaldehyde than healthy tissues (Mani et al., 2016). Quintanilla et al., (2007) observed that the activity of hepatic ADH is significantly escalated after ethanol administration in rats resulting in a marked surge of blood acetaldehyde. Acetaldehyde, as a toxicby-product, can bind to proteins such as enzymes, microsomal proteins, and microtubules. Formation of acetaldehydeprotein adducts in hepatocytes impairs protein secretion, which has been proposed to play a role in hepatomegaly (Agarwal, 2001).

Supplementation of ethanol-administered rats with either RCE or GCE resulted in remarkable reduction in thehepatic activity of $\mathrm{ADH}$ with increase of ALDH activity and significantly ameliorated the oxidative damage induced by ethanol in the hepatic and renal tissues comparing to EtOH-group. The study of Chandrasekhar et al., (2010) showed that chamomile methanolic extracts revealed a dose dependent nephroprotective activity by a significant decreasein lipid peroxidation and increases in the SOD, CAT, GSH and total levels of thiol in the chamomile extract treated groups compared with the ischemia/reperfusion group. Chamomile extract contains polyphenols, chiefly catechins and their derivatives which possess antioxidant, anti-mutagenic and anti-carcinogenic effects that reduce the risk of various forms of cancer, cardiovascular and renal disorders against certain environmental agents (Cemek et al., 2008, 2010). Chamomile has been shown to lower cisplatininduced nephrotoxicity and oxidative stress (Salama et al., 2011 and Salama, 2012). 
In conclusion, the observations of this study confirm that watery extract of gamma-irradiated chamomile (GCE) did not cause any negative effect and caused potent therapeutic effects against alcohol-induced liver and kidney damage. This was evidenced by the improvement in the liver and renal functions, amelioration of hepatic alcohol metabolizing enzymes and thereby the restoration of the liver and kidney antioxidant activities. These results are compatible with the hypothesis that chamomile (Matricaria recutita L.) exerts therapeutic effects by antioxidant and free radical scavenging actions. Therefore, in order to meet national and international standards, it is recommended that gamma irradiation should be integrated into processing protocols for chamomile as a safe food processing method.

\section{References}

Abbondanza, A., Battelli, M.G., Soffritti, M. and Cessi C. (1989) Xanthine oxidase status in ethanolintoxicated rat liver. Alcohol Clin Exp Res, 13, 841.

Abid S. A., Mohammed N. J. and Al-Kaffaji H. A. A. (2012) Effect of Liqurice and Chamomile Extracts in the Management of Gastric Ulcer in Rats. Medical Journal of Babylon 9 (3) :583-597.

AbouSeif H. S. (2014) Ameliorative effect of pumpkin oil (Cucurbitapepo L.) against alcohol-induced hepatotoxicity and oxidative stress in albino rats. Beni-Suef University Journal of Basic and Applied Sciences 3,178- 185.

Aebi, H. (1984) Catalase in vitro. Methods Enzymol., 105, 121-126.

Agarwal, D.P. (2001) Genetic polymorphisms of alcohol metabolizing enzymes. Pathol Biol (Paris). 49, 703-9.

Agarwal, D.P. and Goedde, H.W. (1990) Pharmacogenetics of alcoholdehydrogenase (ADH). Pharmacol Ther, 45, 69-83.

Ahn, H.J., Kim, J.H., Kim, J.K., Kim, D.H., Yook, H.S. and Byun, M.W. (2005) Combined effects of irradiation and modified atmosphere packaging on minimally processed Chinese cabbage (Brassica rapa L.). Food Chemistry, 89, 589-597.

Al-Refai, A.S., Omar, O.A. and Khalil, A.K. (2014) Effect of Chamomile Extract on the Tongue of Chemotherapy Treated Albino Rats
(Histopathological and Immunohistochemical Study). J Clin Cell Immunol 5, 251.

Balasubramaniyan, V., KalaivaniSailaja, J. and Nalini, N. (2003) Role of leptin on alcohol-induced oxidative stress in Swiss mice. Pharmacolog Res. 47, 211.

Caraway, W.T. (1995) Determination of uric acid in serum by a carbonate method. Am J Clin Pathol. 25, 840-5.

Cemek, M., Yilmaz E. and Buyukokuroglu M.E. (2010) Protective effect of Matricariachamomilla on ethanol-induced acute gastric mucosal injury in rats. Pharm. Biol., 48, 757-763

Cemek, M., S. Kaga, N. Simsek, M.E. Buyukokuroglu and M. Konuk, (2008) Antihyperglycemic and antioxidative potential of Matricaria chamomilla L. in streptozotocin-induced diabetic rats. J. Nat. Med., 62, 284-293.

Chandrashekhar, V.M., Ranpariya, V.L., Parashar, A., Muchandi, A.A. and Ganapaty, S. (2010) Neuroprotective activity of Matricaria recutita Linn against global model of ischemia in rats. $J$ Ethnopharmacol 127, 645-51

Coulomb, J.J. and Farreau, L. (1963) A new simple semi-micro method for colourimetric determination of urea. Clinical Chemistry, 9, 102.

Das, S.K. and Vasudevan, D.M. (2005) Biochemical diagnosis of alcoholism. Indian Journal of Clinical Biochemistry. 20 (1), 35-42.

Doumas B.T., Watson W.A. and Biggs H.G. (1971) Albumin standards and the measurement of serum albumin with bromcresol green. Clin Chim Acta. 31, 87-96.

Farkas, J. (1998) Irradiation as a method for decontaminating food: A review,î International Journal of Food Microbiology, 44, 189-204, 1998.

Ghadi F. E., Ghara A. R. and Ghanbari T. (2015) Effect Of Gamma Irradiation On The Total Phenolic Content And Free Radical -Scavenging Activity of Iranian Date Palm Mazafati (Phoenix Dactylifera L.) . International Journal of Latest Research in Science and Technology 4 (5), 149-153.

Gross, R.T., Bracci, R., Rudolph, N., Schroeder, E. and Egypt.J.Rad. Sci. Applic. 39, No.1 (2017) 
Kochen, J.A. (1967) Hydrogen peroxide toxicity and detoxification in the erythrocytes of New Born infants. Blood 29, 481-493.

Gupta, A. and Misra, N. (2006) Hepatoprotective activity of aqueous ethanolic extract of Chamomile capitula in paracetamol intoxicated albino rats, American Journal of Pharmacology and Toxicology. 1, 17-20.

Husdan, H. and A. Rapoport (1968) Estimation of the creatinine by the Jaffe reaction. A comparison of three methods. Clinical Chemistry 14, 222.

IAEA (1992) International Atomic Energy Agency. Irradiation of spices, herbs and other vegetable seasonings. A compilation of technical data for its authorization and control. IAEA-TECDOC, 639.

Jabri, M-A, Sani, M., Rtibi, K., Marzouki, L., ElBenna, J., Sakly, M. and Sebai, H. (2016) Chamomile decoction extract inhibits human neutrophils ROS production and attenuates alcoholinduced haematological parameters changes and erythrocytes oxidative stress in rat. Lipids in Health and Disease, 15, 65.

Jo, C., Son, J.H., Lee, H.J. and Byun, M.W. (2003) Irradiation application for color removal and purification of green tea leaves extract, Radiation Physics and Chemistry, 66, 179-184.

Kaminski, Z.W. and Jewezska, M.M. (1979) Intermediate dehydrogenase oxidase form of xanthine oxidoreductase in rat liver. Biochem $J$. 181, 177-182.

Kassi, E., Papoutsi, Z. and Fokialakis, N. (2004) Greek plant extracts exhibit selective estrogen receptor modulator (SERM)-like properties. J. Agric. Food Chem. 52, 6956-6961.

Kind, P. and King, E. (1954) Estimation of plasma phosphatase by determination of hydrolysed phenol with aminoantipyrine. J Clin Pathol 7, 322.

Kode, A., Rajagopalan, R., Penumathsa, S.V and Menon, V.P. (2004) Influence of a thiazole derivative on ethanol and thermally oxidized sunflower oil-induced oxidative stress, Fund Clin Pharmacol,18, 565.

Lowry, O.H., Rosebrough, N.J., Farr, A.L. and Randall, R.J. (1951) Protein measurement with the Folin phenol reagent. J Biol Chem.193, 265-275.
Mani, V., Siddique, A.I., Arivalagan, S., Thomas, N.S. and Namasivayam N. (2016) Zingerone ameliorates hepatic and renal damage in alcohol-induced toxicity in experimental rats. Int J Nutr Pharmacol. Neurol Dis, 6, 125-32.

Mannaa, F.A., Ibrahim, N.A., Ibrahim, S.S., AbdelWahhab, K.G., Hassan, N.S. and Mohammed, S.G. (2015) Preventive role of chamomile flowers and fennel seeds extracts against liver injury and oxidative stress induced by an immunosuppressant drug in rats. Hepatoma Res. 1, 125-35.

Minami, M. and Yoshikawa, H. (1979) A simplified assay method of superoxide dismutase activity for clinical use.Clin Chim Acta 92, 337-342.

Najla O. A., Olfat A. K., Kholoud S. R. , Enas N. D. and Hanan S. A. (2012) Hypoglycemic and Biochemical Effects of MatricariaChamomilla Leave Extract in Streptozotocin-Induced Diabetic Rats . J. Health Sciences. 2 (5), 43-48.

Nordmann, R., Ribiere, C. and Rouach, H. (1992) Implication of free radical mechanisms in ethanolinduced cellular injury, Free Radic Biol Med, 12, 219.

Nwoye L. O. (2013) Protective and therapeutic effects of ChamomillaRecutita extract on subacute ethanol intoxication in white albino rats African Journal of Biotechnology 12 (18) 2378-2385.

Oyenihi, O. R., Afolabi, B. A., Oyenihi, A.B., Ogunmokuna O.J. and Oguntibejuc O. O. (2016) Hepato- and neuro-protective effects of watermelon juice on acute ethanol-induced oxidative stress in rats. Toxicology Reports 3, 288-294

Ozaras, R., Tahan, V., Aydin, S., Uzun, H., Kaya, S. andSenturk, H. (2003) N acetylcysteine attenuates alcohol induced oxidative stess in rats. World $J$ Gastroenterol 9, 7914.

Padmanabhan, P. and Jangle, S.N. (2014) Hepatoprotective activity of herbal preparation (HP-4) against alcohol Induced hepatotoxicity in mice. Int J Appl Sci Biotechnol, 2 (1), 50-8.

Purohit, V., Russo, D. and Salin, M. (2003) Role of iron in alcoholic liver disease: Introduction and summary of the symposium. Alcohol. 30, 937.

Quintanilla, M.E., Tampier, L., Sapag, A., Gerdtzen, Z. and Israel, Y. (2007) Sexdifferences, alcohol 
dehydrogenase, acetaldehyde burst, and aversion to ethanol in the rat: A systems perspective. Am $J$ Physiol Endocrinol Metab, 293, E531-7.

Reitman, S. and Frankel, S. (1957) A calorimetric method for the determination of serum glutamic oxalacetic and glutamic pyruvic transaminases. Am. J. Clin. Pathol 28, 56.

Rodrigo, R., Thielemann, L., Olea, M, Muñoz, P., Cereceda, M. and Orellana, M.. (1998) Effect of ethanol ingestion on renal regulation of water and electrolytes. Arch Med Res 29, 209-18.

Rodrigo, R., Trujillo, S., Bosco, C., Orellana, M., Thielemann, L. and Araya, J. (2002) Changes in $(\mathrm{Na}+\mathrm{K})$-adenosine triphosphatase activity and ultra structure of lung and kidney associated with oxidative stress induced by acute ethanol intoxication. Chest. 121, 589.

Rosalki SB. (1975) Gamma-glutamyltranspeptidase. Advclin Chem. 17, 53-107.

Salama, R.H.M. (2012) Matricaria chamomilla attenuates cisplatin nephrotoxicity. Saudi J. Kidney Dis. Transplant. 23, 765-772

Salama, R.H.M., N.A.M. Abd-El-Hameed, S. Abd-El-
Ghaffar, Z.T. Mohammed and N.M.A. Ghandour, (2011) Nephroprotective effect of Nigella sativa and Matricaria chamomilla in cisplatin induced renal injury. Int. J. Clin. Med., 2, 185-195.

Saravanan, N. and Nalini, N. (2007) Impact of Hemidesmus indicus R.Br. extract on ethanolmediated oxidative damage in rat kidney. Redox Rep . 12 (5), 229-35.

Sebai, H., Jabri, M.A., Souli, A., Rtibi, K., Selmi, S. and Tebourbi, O. (2014) Antidiarrheal and antioxidant activities of chamomile (Matricaria recutita L.) decoction extract in rats. J Ethnopharmacol. 152, 327-32.

Singh, D. and Singh, A. (2002) Biochemical alteration in freshwater fish Channapunctatusdue to latices of Euphorbia royleanaandJatrophagossypifolia. Environmental Toxicology and Pharmacology. 12, 129-31.

SPSS. (1998) Statistical Package for Social Science. Computer Software, Ver. 10. SPSS Company, London, UK.

Yoshioka, T., Kawada, K., Shimada, T. and Mori, M. (1979) Lipid peroxidation in maternal and cord blood and protective mechanism against activated-

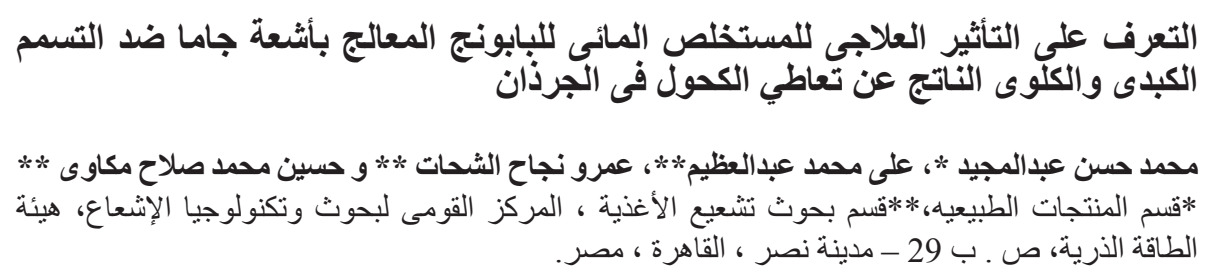

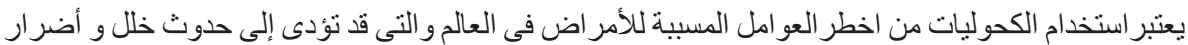

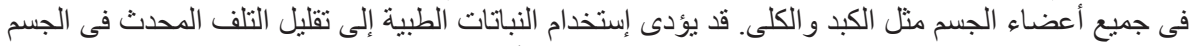

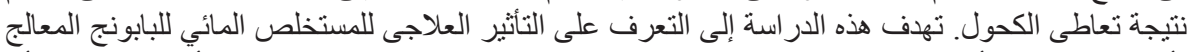

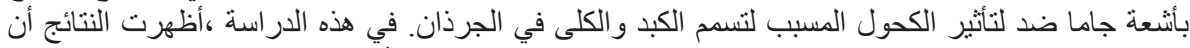

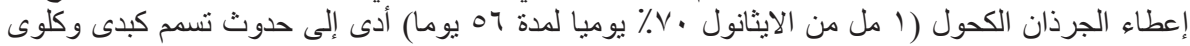

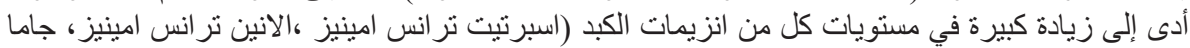

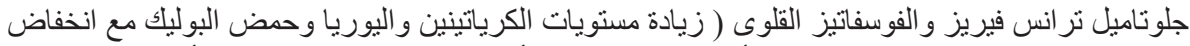

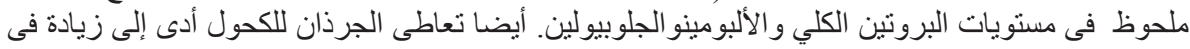

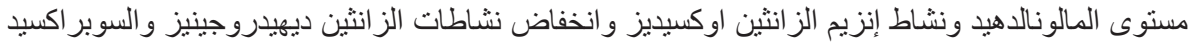

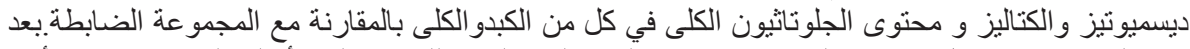

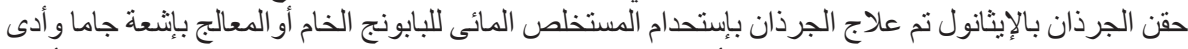

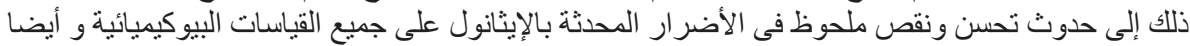

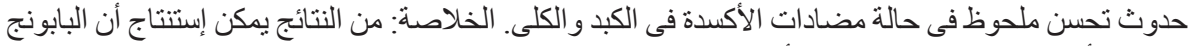
المعالج بأثععة جاما يمكن استخدامه كأحد الطرق العلاجية ضدالتلف الناجم الندم عن تعاطى الكحوليات. 